\title{
Alkaloids, Limonoids and Phenols from Meliaceae Species Decrease Survival and Performance of Hypsipyla grandella Larvae
}

\author{
Julián Pérez-Flores $^{1 *}$, Sanford D. Eigenbrode ${ }^{2}$, Luko Hilje-Quiroz ${ }^{3}$ \\ ${ }^{1}$ Colegio de Postgraduados-Campus Tabasco, H. Cárdenas Tabasco, México; ${ }^{2}$ PSES Department, University of Idaho, Moscow, USA; \\ ${ }^{3}$ Centro Agronómico Tropical de Investigación y Enseñanza (CATIE), Turrialba, Costa Rica. \\ Email: *julianflores@colpos.mx
}

Received May $2^{\text {nd }}, 2012$; revised May $30^{\text {th }}, 2012$; accepted June $9^{\text {th }}, 2012$

\begin{abstract}
Meliaceae plants are distinguished by the attack of the shootborer Hypsipyla grandella and also for the occurrence of limonoids, alkaloids and phenolic compounds. Such compounds extracted from leaves of Meliaceae species Cedrela odorata L., Swietenia macrophylla King, Khaya senegalensis, Toona ciliata, and C. odorata grafted onto T. ciliata plants, were tested on C. odorata leaf disks to determine their effects on survival and performance of $H$. grandella larvae. Larval survival was assessed 2, 10 and 25 days after starting the bioassays. Leaf consumption and weight gain per larva, days to pupa and to adult stages, pupal weight and length, and moth wing appearance were assessed for larval performance. The three compounds from the four Meliaceae species and the grafted combination affected $(\mathrm{P} \leq 0.02)$ larval leaf consumption, weight gain, time to pupa and to adult stages, wing development and larval survival of $H$. grandella. Pupa weight $(\mathrm{P}=0.78, \mathrm{~F}=0.72$, d.f. $=18,160)$ and length $(\mathrm{P}=0.48, \mathrm{~F}=0.98$, d.f. $=18,160)$ were similar regardless of the coumpound used. Limonoid reduced larval survival on the three dates of evaluation. Alkaloids decreased leaf consumption, weight gain of larvae and time needed to reach pupa and adult stages. Alkaloids from T. ciliata and phenols from $C$. odorata were the best coumpounds to reduce leaf consumption and weight gain. Alkaloids from the grafted plants caused $20 \%$ of $H$. grandella adults to form abnormal wings.
\end{abstract}

Keywords: Leaf Extracts; Cedrela; Swietenia; Khaya; Toona; Shootborer

\section{Introduction}

High-quality timber from Spanish cedar (Cedrela odorata L.) and mahogany (Swietenia macrophylla King) is of major significance for economies in many neotropical countries [1]. Unfortunately, natural populations of these species are being reduced quickly due to selective harvest [2]. In addition, the mahogany shootborer, Нypsipyla grandella (Zeller) (Lepidoptera: Pyralidae), has limited their establishment in commercial plantations in Latin America, as its larva mainly feeds on apical shoots, inducing branching on the trees and rendering the timber unmarketable [3]. Larvae also can feed on fruits, leaves, bark, and root tissues.

In tree tissues internal chemicals may exert their effect in the volatile state causing an insect to avoid the tree completely, or they may deter the insect after it contacts the tree or ingests tissue [4]. Research on the biochemical basis for resistance to $H$. grandella in Meliaceae has been completed on limonoids [5,6], while Gripjma [7]

${ }^{*}$ Corresponding author. indicated that the biochemical basis for resistance of Toona ciliata (Meliaceae) may be due to alkaloids. Further, Newton et al. [8] suggested that proantocianydins (i.e. phenolic compounds) may reduce susceptibility of $C$. odorata to attack by $H$. grandella larvae.

The family Meliaceae stands out because of the common occurrence of limonoids [9], which possess antifeedant, toxic, or growth-reducing properties to different species of insects [10]. Azadirachtin, the most wellknown limonoid [11] was toxic to the Meliaceae's shootborer $H$. grandella larvae when incorporated in diet mixtures [7]. Such toxic effect plus growth-disruptant activity were reported by Mancebo et al. [12] for azadirachtin. Limonoids, however, seemed unrelated to the induced resistance of $C$. odorata grafted onto $T$. ciliata against $H$. grandella larvae [6]; instead, these authors stated that phenols (cycloartanes, catechin and proanthocyanidins) were likely responsible for such resistance, as all of them were absent from C. odorata scions or intact (non-grafted) plants but present in $T$. ciliata.

Phenols such as methylcoumarins and the furanocou- 
marin bergapten have been found in T. ciliata [13], proanthocyanidins in C. odorata [8], and the flavonoids quercitin and kaenferol in C. odorata and T. ciliata [14]. Furanocoumarins are potent feeding deterrents to certain insect species [15], and bergapten might promote the resistance of $T$. ciliata against $H$. grandella larvae. Other chemicals found in Meliaceae species which provide resistance against $H$. grandella are alkaloids. Alkaloids are nitrogen compounds that function as plant defenses against herbivores [16] and were detected in ethanolic extracts from $T$. ciliata [17]. These extracts were toxic to and reduced growth on $H$. grandella larvae [18]. For this reason, alkaloid compounds could be responsible for the resistance of $T$. ciliata against $H$. grandella larvae.

Therefore, the objective of the research was to detect the effects of alkaloid, limonoid, and phenolic extracts from foliage of susceptible and resistant Meliaceae species, as well as from $C$. odorata grafted onto $T$. ciliata plants, on $H$. grandella larval survival and performance. The hypothesis to test was that the three different compounds from the susceptible and resistant Meliaceae species as well as from the grafted plants affect larval survival and performance of the Meliaceaes shootborer.

\section{Materials and Methods}

\subsection{Plant Material and Extract Preparation}

The extracts were prepared in the Animal Nutrition Laboratory at the Tropical Agricultural Research and Higher Education Center (CATIE), in Turrialba, Costa Rica, from the susceptible Meliaceae species C. odorata and S. macrophylla, the resistant species Khaya senegalensis and T. ciliata as well as from C. odorata grafted onto T. ciliata plants. Plants were grown from seeds in a nursery at the Cabiria Experiment Station, within the premises of CATIE.

Fresh leaves and shoots $(500 \mathrm{~g})$ from 1-year-old plants were cut into 2 to $5 \mathrm{~cm}$ pieces, and then ground in liquid nitrogen to $0.05 \mathrm{~mm}$ in a mill (Model 3 Wiley Mill ${ }^{\circledR}$, Thomas Co., Philadelphia). Later, the ground material was extracted with 2 L 70/30 methanol/water by volume. Extraction was completed at room temperature $\left(20^{\circ} \mathrm{C}\right)$ for $8 \mathrm{~d}$. Each extract was filtered through Whatman paper No. 4, and the extract was concentrated to a small volume $(200 \mathrm{~mL})$ by a rotary evaporator $\left(40^{\circ} \mathrm{C}\right.$ ) (so all methanol was removed). Each concentrate was partitioned among ether and dichloromethane to produce extracts likely to contain predominantly alkaloids, phenols and limonoids, respectively.

Alkaloid and phenolic fractions. These compounds were isolated by the acid-base separation method [19]. Back extraction of the ether extract with $0.5 \mathrm{M} \mathrm{HCl}$ removed amine bases such as alkaloids. A second extrac- tion of the remaining ether extract with $0.5 \mathrm{M} \mathrm{NaOH}$ removed phenols, which are ionizable at high $\mathrm{pH}$. The basic and phenolic compounds were recovered by adjusting the $\mathrm{pH}$ of each extract to the point where the compounds were present in their uncharged forms (alkaloids, $\mathrm{pH} \cong 11$; phenols, $\mathrm{pH} \cong 7$ ).

Limonoid fractions. For the isolation of limonoids 25 $\mathrm{mL}$ of crude extract were separated on a silica gel column $(400 \mathrm{~mm} \times 8 \mathrm{~mm}$, Silica Gel grade 60, 254 g gravity flow), and then eluted with dichloromethane [20]. This dichloromethane fraction was then concentrated to a small volume $(50 \mathrm{~mL})$ by a rotary evaporator and then used in the bioassays.

\subsection{Test Insects}

Hypsipyla grandella larvae for bioassays were taken from a colony kept at the Entomology Laboratory at CATIE. The colony was established in 1998, and renewed yearly, from field-collected larvae feeding on $C$. odorata. Larvae in the colony are normally fed with tender C. odorata leaves from instars I-III, and then placed onto an artificial diet [21] until pupation. Combining leaves and artificial diet ease the management of the colony. Eggs hatch hardly on diet but easily on leaves. Feeding larvae only with leaves is hard since they are so voracious that if they do not have anything to eat they eat each other. On another hand, tender leaves are scarce on dry season. Pupae are moved to a metal-framed cage covered with fine mesh, kept at a greenhouse, where adults emerge, mate, and oviposit. Eggs are collected and taken to the laboratory to sustain the colony.

Instar II larvae (4 - $8 \mathrm{~mm}$ length) were selected for bioassay because they are less sensitive to handling than instar I and approximate what would occur in nature regarding initial plant attack by $H$. grandella larvae. Instar II bores into the apical bud only after feeding on tender petioles and foliage [3].

\subsection{Bioassays}

The bioassay was completed in an environmental chamber Percival I35-L (Boone, Iowa) at $25 \mathrm{C}, 80 \%$ to $90 \%$ $\mathrm{RH}$, and 12:12 L:D, at the Entomology Laboratory at CATIE, from October 15 through December 6, 2005. Cedrela odorata leaf disks were taken from plants as the food source for rearing the $H$. grandella colony. Leaf disks were cut from central leaflets, by using a cork borer (2.30 $\mathrm{cm}$ diameter). Ten leaf disks per treatment were put on a Petri dish and then sprayed with $12 \mu \mathrm{L} \cdot \mathrm{cm}^{-2}$ of each extract added with $0.03 \%$ Citowett (BASF, Canada, Inc.) as surfactant agent. The application of extracts to leaf disks was done by using a De Vilbiss 15 sprayer (The De Vilbiss, USA) connected to a vacuum pump (GAST ${ }^{\mathrm{TM}}$ 
DOA-P104-AA, GAST Manufacturing Corp. Benton Harbor, Michigan), with $0.7 \mathrm{~kg} \cdot \mathrm{cm}^{-2}$ constant pressure. Sprayed leaf disks were allowed to dry and were placed individually, with the abaxial side up, inside a $30-\mathrm{mL}$ glass vial. Then, an instar II $H$. grandella larva was placed onto the leaf disk. Larvae had been deprived of food for $3 \mathrm{~h}$ [12]. A wet piece of paper towel was fastened to the lid of each vial to avoid excessive desiccation of leaf disks. The vial was then turned over so the larva was below the leaf disk.

\subsection{Assessments}

All of the larvae were weighed before and $2 \mathrm{~d}$ after starting the bioassay and then an average weight gain per larva per treatment was calculated by subtracting initial from final weight. Also after $2 \mathrm{~d}$, larval survival was assessed and leaf consumption estimated. To estimate leaf consumption, the disk was glued to a transparent film and then overlayed onto graph paper $\left(1 \mathrm{~mm}^{2}\right.$ grid size $)$ to count the leaf area eaten. Living larvae were individually transferred by means of a thin paintbrush into a vial containing ca. $6 \mathrm{~mL}$ of artificial diet [21], and then reared until adult emergence. Larval survival at 2, 10 and $25 \mathrm{~d}$ after starting bioassay, time (days) to achieve the pupa and adult stages, pupal weight (mg) and length (mm), and wing shape were all determined for these larvae.

Larval and pupal mortality were recorded as 0 and 1 for dead and live larvae, respectively, since just one larva was used per leaf disk. Larvae were classified as dead if they were immobile or blackened. Pupae were classified as dead if they failed to emerge after 45 days or if they appeared blackened or shriveled [12]. Data for pupa were determined 1 day after pupation. On the day of adult emergence, wing shape was recorded after wing expansion and drying were completed. Normal and abnormal wings were recorded as 0 and 1 , respectively. Wings were considered normal when both forewings were similar in length and covered the whole abdomen longitudenally [22]. Abnormalities included absence or rudimenttary forewings or shortened forewings exposing the abdomen. To exclude possible effects of the artificial diet alone on these characteristics, 100 pupas were selected at random from the colony and reared to adults. None of these insects had abnormal wings.

\subsection{Experimental Procedure and Statistical Analysis}

The bioassay was replicated three times. Each bioassay consisted of 19 treatments: five limonoid, alkaloid and phenolic extracts with each one from the four Meliaceae species and the grafted plants, dichloromethane and ether solvents as well as larvae without leaf disk as relative controls, and distilled water as absolute control. The experimental unit was a leaf disk with one instar II $H$. grandella larva in a capped vial. The vials were arranged in a completely randomized design with a factorial arrangement of treatments. The factors were the extract (limonoids, alkaloids and phenols) and the source of extract (C. odorata, S. macrophylla, K. senegalensis, $T$. ciliata, and the grafted combination $C$. odorata onto $T$. ciliata). Each treatment was replicated 10 times.

Data were examined for compliance of assumptions required for analysis of variance (ANOVA). If necessary, data were transformed by $\mathrm{Y}=\operatorname{sqrt}(\mathrm{Y}+0.5)$ to meet these assumptions. ANOVA was completed using the general lineal model (GLM) procedure [23]. Orthogonal contrasts were used to test the effect of alkaloids, limonoids and phenols on larval survival and performance. The contrasts were as follows: 1) alkaloids versus limonoids, 2) alkaloids versus phenols, and 3) limonoids versus phenols.

\section{Results and Discussion}

The three kind of compounds from leaves of the four Meliaceae species and the grafted combination affected $(P \leq 0.02)$ larval leaf consumption, weight gain, time to pupa and to adult stages, wing development and larval survival of $H$. grandella (Table 1). Pupa weight $(\mathrm{P}=$ $0.78, \mathrm{~F}=0.72$, d.f. $=18,160)$ and length $(\mathrm{P}=0.48, \mathrm{~F}=$ 0.98 , d.f. $=18,160$ ) were similar regardless of the extract used.

\subsection{Larval Survival}

Alkaloids, limonoids and phenols affected larval survival differently (Table 1) at 2, 10 and 25 days after starting bioassay. Fewer larvae reared on disks sprayed with limonoids survived compared to larvae reared on disks sprayed with alkaloids or phenols similar to the neemderived Azadirachtin [16]. These authors reported that small amounts of ingested $C$. odorata leaf disks dipped in Azadirachtin 10\% were enough to kill $100 \%$ of larvae in a $24 \mathrm{~h}$ period of exposure.

Reduction of larval survival at $2 \mathrm{~d}$ after starting bioassay was most notable for limonoid extracts from $K$. senegalensis, compared to alkaloids from $C$. odorata or from the grafted plants and phenols from $K$. senegalensis or from T. ciliata. A similar trend on larval survival was observed at 10 and $25 \mathrm{~d}$ after starting bioassay; larval survival was reduced by limonoids from $S$. macrophylla and $K$. senegalensis compared to alkaloids from $S$. macrophylla or from the grafted plants and also compared to phenols from $K$. segalensis or from T. ciliata; such reduction on larval survival by limonods was only comparable to this of larvae without leaf disk (Figure 1). These results could indicate toxicity of limonoids from 
Table 1. Probability values for orthogonal contrasts and ANOVA for several variables assessed in a bioassay with Hypsipyla grandella larvae on Cedrela odorata foliar disks treated with alkaloids, limonoids and phenols extracts from Meliaceae species and a graft combination.

\begin{tabular}{|c|c|c|c|c|c|c|c|c|}
\hline \multirow{2}{*}{ Contrast } & \multirow{2}{*}{$\begin{array}{c}\text { Leaf } \\
\text { consumption } \\
\left(\mathbf{m m}^{2}\right)\end{array}$} & \multirow{2}{*}{$\begin{array}{l}\text { Weight gain } \\
\text { (mg) }\end{array}$} & \multicolumn{2}{|c|}{ Days to } & \multirow{2}{*}{$\begin{array}{l}\text { Normal } \\
\text { wings }\end{array}$} & \multicolumn{3}{|c|}{ Larval survival } \\
\hline & & & Pupa & Adult & & 2 DAS & 10 DAS & 25 DAS \\
\hline & \multicolumn{8}{|c|}{ Probabilities } \\
\hline Alkaloids vs limonoids & 0.71 & $<0.0001$ & 0.59 & 0.34 & 0.02 & 0.39 & 0.09 & 0.84 \\
\hline Alkaloids vs phenols & 0.90 & $<0.0001$ & 0.44 & 0.46 & 0.06 & 0.13 & 0.41 & 0.07 \\
\hline Limonoids vs phenols & 0.80 & 0.91 & 0.19 & 0.84 & 0.67 & 0.02 & 0.01 & 0.05 \\
\hline \multicolumn{9}{|l|}{ ANOVA } \\
\hline $\mathrm{P}$ & $<0.0001$ & $<0.0001$ & 0.007 & 0.001 & 0.0003 & $<0.0001$ & 0.0008 & 0.02 \\
\hline $\mathrm{F}$ & 3.15 & 97.94 & 2.12 & 2.51 & 2.81 & 4.94 & 2.58 & 1.86 \\
\hline d.f. & 17,162 & 18,171 & 18,161 & 18,154 & 18,153 & 18,171 & 18,170 & 18,170 \\
\hline
\end{tabular}

Abbreviations: DAS, days after starting the bioassay. Data are from three bioassays combined into one data set analysis.

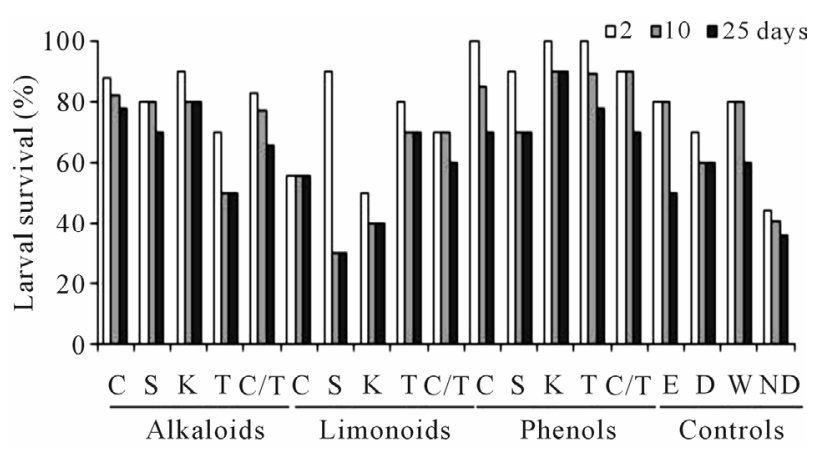

Figure 1. Survival of instar II $\mathrm{H}$. grandella larvae exposed for $2 \mathrm{~d}$ to $C$. odorata leaf disks treated with alkaloids, limonoids, and phenols from four Meliaceae species and a graft combination. Data were taken 2, 10 and $25 \mathrm{~d}$ after starting bioassay. $\mathrm{C}=C$. odorata, $\mathrm{S}=S$. macrophylla, $\mathrm{K}=\mathrm{K}$. senegalensis, $\mathrm{T}=\mathrm{T}$. ciliata, $\mathrm{C} / \mathrm{T}=\mathrm{C}$. odorata grafted onto $\mathrm{T}$. ciliata, $\mathbf{E}=$ Ether, $\mathbf{D}=$ Dichloromethane, $\mathbf{W}=$ Water. Data are means $(n=30)$ from three bioassays.

K. senegalensis or S. Macrophylla against $H$. grandella larvae. Chronic toxicity on Spodopthera littoralis (Lepidoptera: Pyralidae) larvae was caused by extracts from Reynoutria sp. (Polygonaceae) plants containing phenollic compounds [20]. Althought S. littoralis and H. grandella belong to the same family, they are different genera. Also, the difference between our results and those of Pavela et al. [24] can be attributed to the kind of phenols contained on Reynoutria and Meliaceae species.

The lowest larval survival scored $(30 \%)$ was caused for limonoids from S. macrophylla (Figure 1), but this results differed from those of Pérez et al. [25] who found that besides causing deterrence, crude extracts from Meliaceae species, specifically the extracts from $T$. ciliata species, decreased up to $0 \% \mathrm{H}$. grandella larval survival. Such difference seems consistent with a prob- able sinergestic effect of multiple defenses [26]. Anyway, limonoids and phenols differed only for larval survival but not for larval performance variables (Table 1).

\subsection{Larval Performance}

Consumed leaf area and weight gain. These variables had a direct relation when leaf disks were sprayed with limonoid extracts (Figure 2). Although limonoids seemed to have a phagoestimulatory effect on H. grandella larvae, larvae weight gain was lower than the expected, or larvae died after leaf consumption. Limonoids may be found in all tissues on plants, but different plant organs may produce different kinds of limonoids [10] with different action on plant protection.

The alkaloid and phenol effects depended on the plant source for leaf consumption. The alkaloids from grafted plants reduced $H$. grandella leaf consumption compared to alkaloids from C. odorata or limonoids and phenols from S. macrophylla and also compared to the control water. In contrast, limonoid from $K$. senegalensis and $C$. odorata differed to limonoids from S. macrophylla, $T$. ciliata and the graft combination in their effect on leaf consumption. Phenols from C. odorata and T. ciliata reduced leaf consumption compared to those of the other two species and the grafted plants (Figure 2(a)).

Larval weight gain differed among larvae fed with alkaloids. The alkaloid fraction effect on weight gain was more notable between S. macrophylla and grafted plants. From grafted plants alkaloid fractions reduced weight gain more than phenols or limonoids (Figure 2(b)). Except for phenols from C. odorata or T. ciliata which reduced weight gain, the other phenols were similar each other and also were similar to the control water to allow weight gain of $H$. grandella larvae. Limonoids from 
Cedrela spp. mixed in an artificial diet showed a postdigestive toxicity for Spodoptera frugiperda neonates, reducing growth and causing significant mortality after rearing [20].

Although phenols differed from alkaloids on weight gain (Table 1), phenols from C. odorata and alkaloids from the grafted plants reduced the leaf consumption by $H$. grandella to the same level (Figure 2(a)). Such results caused by alkaloids from the grafted plants agree with the hypothesis suggested by Grijpma [7] about the transfer of alkaloids from $T$. ciliata to $C$. odorata to confer resistance in this susceptible scion.

Time to pupa and to adult stages. All of the tested compounds from S. macrophylla, as well as limonoids from the grafted plants or phenols from $T$. ciliata, reduced the time to pupation by 2 and $4 \mathrm{~d}$ compared to water and no-disk controls, respectively; but their effect was similar to the other controls (Figure 3(a)). All of the compounds that reduced the time to pupation, also re- duced the time to the adult stage by a difference of $5 \mathrm{~d}$ compared to the no-disk control, but their effect was again similar to all the other controls and extracts from the various species (Figure 3(b)).

Alkaloids from grafted plants and limonoid from $C$. odorata or from $K$. senegalensis seemed to delay pupation compared to the other fractions (Figure 3(a)). Such treatments and the phenols from $C$. odorata also seemed to delay adulthood compared to the controls ether and dichloromethane (Figure 3(b)). However, H. grandella larval development last about $30 \mathrm{~d}$ and pupation about 10 to $12 \mathrm{~d}$ [27], therefore the three evaluated compounds reduced time to pupa and to adult stage. Pérez et al. [25] cited that $H$. grandella larvae fed leaf disks from $K$. senegalensis grafted onto $S$. macrophylla extended by 10 $\mathrm{d}$ both time to reach pupa and to adult stages $(34.3 \pm 3.8$ d vs. $24.3 \pm 0.5 \mathrm{~d}$; and $45.2 \pm 2.8$ vs. $35.2 \pm 1.3 \mathrm{~d}$, respectively) compared to larvae fed $C$. odorata leaf disks. Also, these authors cited that crude extracs from grafted

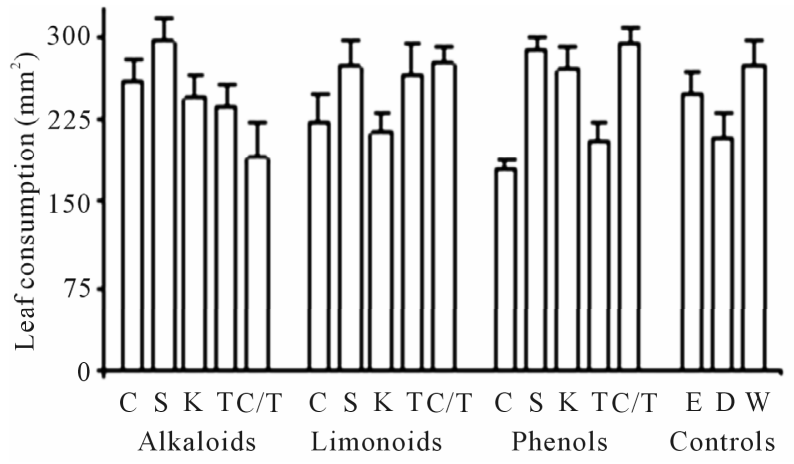

(a)

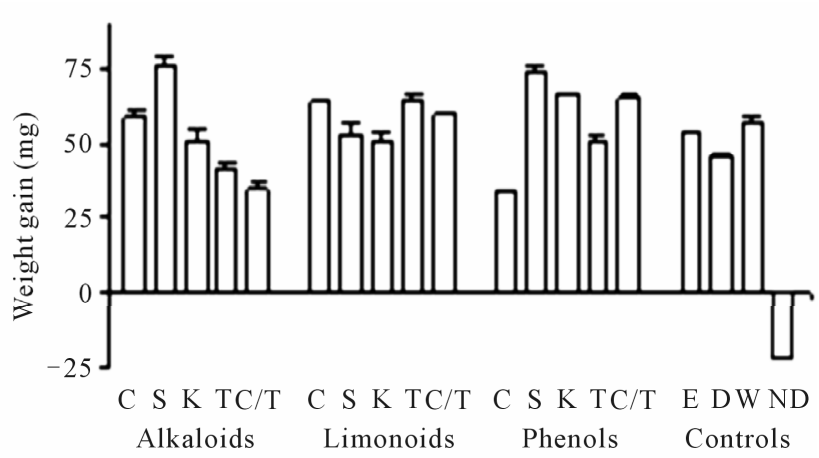

(b)

Figure 2. Leaf consumption (a) and weight gain (b) for instar II Hypsipyla grandella larva reared on Cedrela odorata leaf disks treated with alkaloids, limonoids and phenols from four Meliaceae species and a graft combination. $\mathrm{C}=\mathrm{C}$. odorata, $\mathrm{S}=\mathrm{S}$. macrophylla, $\mathrm{K}=\mathrm{K}$. senegalensis, $\mathrm{T}=\mathrm{T}$. ciliata, $\mathrm{C} / \mathrm{T}=\mathrm{C}$. odorata grafted onto $\mathrm{T}$. ciliata, $\mathrm{E}=\mathrm{Ether}, \mathrm{D}=\mathrm{Dichloromethane}, \mathrm{W}=$ Water, ND = Larva without leaf disk. Data were taken $2 \mathrm{~d}$ after starting bioassay. Data are means $( \pm \mathrm{SE}, \mathrm{n}=30)$ from three bioassays.

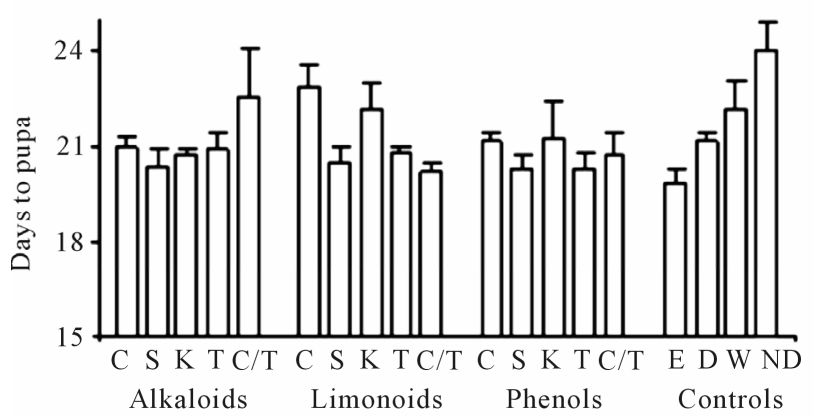

(a)

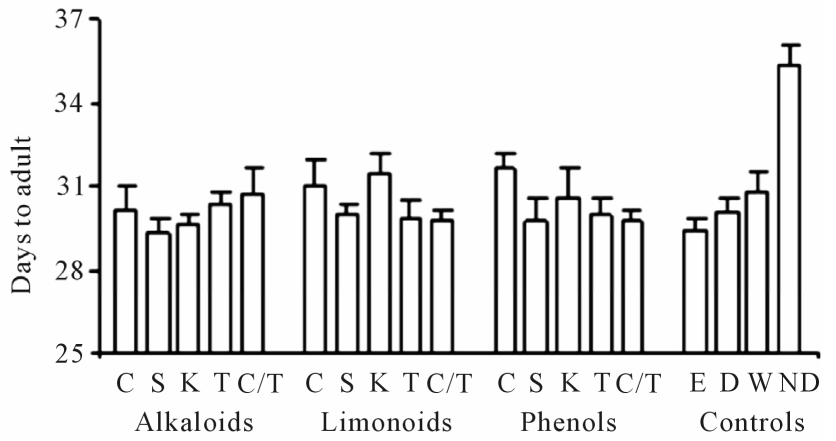

(b)

Figure 3. Time to pupa (a) and to adult (b) stages of Hypsipyla grandella larvae reared on C. odorata leaf disks treated with alkaloids, limonoids, and phenols from four Meliaceae species and a graft combination. $\mathrm{C}=\mathrm{C}$. odorata, $\mathrm{S}=\mathrm{S}$. macrophylla, $\mathrm{K}$ $=K$. senegalensis, $\mathrm{T}=\mathrm{T}$. ciliata, $\mathrm{C} / \mathrm{T}=\mathrm{C}$. odorata grafted onto $\mathrm{T}$. ciliata, $\mathrm{E}=$ Ether, $\mathrm{D}=$ Dichloromethane, $\mathrm{W}=\mathrm{W}$ ater, $\mathrm{ND}=$ Larva without leaf disk. Data are means $( \pm \mathrm{SE}, \mathrm{n}=30)$ from three bioassays. 
and intact Meliaceae plants affected $(\mathrm{P} \leq 0.05)$ both variables. Pavela et al. [24] observed a larval period increased on neonate larvae of Spodoptera littoralis by feeding them with diet containing different concentrations of crude extracts of Reynoutria sp. (Polygonaceae) which contained phenolic compounds.

Moth wing appearance. Development of wings was affected $(\mathrm{P}=0.0003, \mathrm{~F}=2.81$, d.f. $=18,153)$ by the tested compounds. Alkaloids from grafted plants and phenols from $T$. ciliata caused $20 \%$ and $4 \%$ of adults with abnormal wing shape, respectively. All larvae fed leaf disks treated with any other compound got from any other plant or the controls formed normal wings when they developed into adult moths. These results are consistent with those of Pérez et al. [25] who reported abnormal wings formed on $H$. grandella larvae fed leaf disks from $K$. senegalensis, $K$. senegalensis grafted onto S. macrophylla, C. odorata grafted onto K. senegalensis, or from S. macrophylla grafted onto K. senegalensis. The same authors reported abnormal wings developed on one adult fed on C. odorata leaf sprayed with crude foliar extract from C. odorata grafted onto T. ciliata. Development disruption was reported for Locusta migratoria due to limonoid Azadirachtin at $1-10 \mathrm{ppm}$ in artificial diets [28].

Meliaceae plants stands out by the occurrence of limonoids [9], but other secondary compounds such as flavonoids, alkaloids, terpenes and antraquinones have been isolated from Toona sinensis leaves [29] and recently 12 phenolic compounds have been identified in this species [30]. The primary selective advantage of the production of secondary compounds on plants is protection against insect herbivory. In this way, limonoids Cedrelone and Anthotecol from Toona and Khaya spp. showed potent growth reducing activity to Spodopthera frugiperda, Heliothis zea, Pectinophora gossypiela and Ostrinia nubilalis larvae [10]. Also from the same species, limonoids Bussein and Anthotecol inhibited ecdysis on O. nubilalis.

Taking into account that an efficient control for $H$. grandella is currently lacking due to the low damage threshold of one larva per plant [31], the extracts represent potentially useful raw material for developing microinjections or implants into tree stems as slow-release formulas, increasing their persistence. A further step would be to identify the specific alkaloid, limonoid, and phenol that act against $H$. grandella in order to synthesize, combine, and incorporate them in commercial products. Such products could be deployed to protect Cedrela spp. and Swietenia spp. trees for 5 to 8 years (critical period to $H$. grandella), which is the time required to achieve a commercial trunk for these species, depending on the site where they grow [32].

\section{Conclusion}

This study demonstrates that survival of Hypsipyla grandella larvae is affected by limonoids, specifically those extracted from S. macrophylla and $K$. senegalensis. Alkaloids reduced leaf consumption and weight gain per larva compared to limonoids and phenols and those extracted from S. macrophylla were the best to reduce time to pupa and to adult stages compared to the starved control. Alkaloids from C. odorata grafted onto T. ciliata and phenols from $T$. ciliata caused abnormal wing shape on $H$. grandella moths. Therefore, our hypothesis that alkaloids, limonoids and phenols from the susceptible and resistant Meliaceae species, as well as from the grafted plants, affect larval survival and performance of the Meliaceae's shootborer was accepted.

\section{Acknowledgements}

J. P. F. thanks to CONACYT and the Colegio de Postgraduados (México), and the Department of Plant, Soil and Entomological Sciences at the University of Idaho (USA) for providing founds for this research.

\section{REFERENCES}

[1] A. C. Newton, P. Baker, S. Ramnarine, J. F. Mesén and R. R. B. Leakey, "The Mahogany Shoot Borer: Prospects for Control," Forest Ecology Management, Vol. 57, No. 1-4, 1993, pp. 301-328. doi:10.1016/0378-1127(93)90179-Q

[2] P. D. Albert, A. A. López, T. M. Rodríguez and R. M. Duarte, "Recursos Fitogenéticos Forestales, I. Familia Meliaceae," Fontqueria, Vol. 42, 1995, pp. 329-351.

[3] P. Grijpma, "Studies on the Shoot-borer Hypsipyla grandella (Zeller) (Lepidoptera, Pyralidae). V. Observation on Rearing Technique and on Host Selection Behavior of Adults in Captivity," Turrialba, Vol. 21, 1971, pp. 202-213.

[4] S. A. Cunningham and R. B. Floyd, "Leaf Compositional Differences Predict Variation in Hypsipyla robusta Damage to Toona ciliata in Field Trials," Canadian Journal of Forest Research, Vol. 34, No. 3, 2004, pp. 642-648. doi: $10.1139 / \mathrm{x} 03-228$

[5] M. F. Das G. F. Da Silva, S. M. M. Agostinho, J. R. De Paula, J. O. Neto, I. Castro-Gamboa, R. E. Filho, J. B. Fernandes and P. C. Vieira, "Chemistry of Toona ciliata and Cedrela odorata Graft (Meliaceae): Chemosystematic and Ecological Significance," Pure and Applied Chemistry, Vol. 71, No. 6, 1999, pp. 1083-1087. doi:10.1351/pac199971061083

[6] J. R. De Paula, I. J. C. Vieira, M. F. Das G. F. Da Silva, F. E. Rodriguez, J. B. Fernandes, P. C. Vieira, A. L. Pinheiro and E. F. Vilela, "Sesquiterpenes, Triterpenoids, Limonoids and Flavonoids of C. odorata Graft and Speculations on the Induced Resistance against Hypsipyla grandella," Phytochemistry, Vol. 44, No. 8, 1997, pp. 1449-1454. doi:10.1016/S0031-9422(96)00747-9 
[7] P. Grijpma, "Resistance of Meliaceae against the Shoot Borer Hypsipyla grandella with Particular Reference to Toona ciliata M.J. Roem. var. australis (F. \& M.) C.D.C.," In: J. Burley and B. T. Styles, Eds., Tropical Trees: Variation, Breeding and Conservation, Academic Press, London, England, 1976, pp. 69-78.

[8] A. C. Newton, A. D. Watt, F. López, J. F. Cornelius, J. F. Mesén and E. A. Corea, "Genetic Variation in Host Susceptibility to Attack by the Mahogany Shoot Borer, Hypsipyla grandella (Zeller)," Agricultural and Forest Entomology, Vol. 1, 1999, pp. 11-18. doi:10.1046/j.1461-9563.1999.00002.x

[9] D. H. A. Taylor, "Chemotaxonomy: the Occurrence of Limonoids in the Meliaceae," In: T. D. Pennington, Ed., Flora Neotropica, The New York Botanical Garden, 1981, pp. 450-458.

[10] D. E. Champagne, O. Koul, M. B. Isman, G. G. E. Scuder, and G. H. N. Towers, "Biological Activity of Limonoids from the Rutales," Phytochemistry, Vol. 31, No. 2, 1992, pp. 377-394. doi:10.1016/0031-9422(92)90003-9

[11] R. C. Saxena, "Insecticides from Neem," In: J. T. Arnason, B. J. R. Philogéne and P. Morand, Eds., Insecticides of Plant Origin, American Chemical Society, Washington DC, 1989, pp. 110-135. doi:10.1021/bk-1989-0387.ch009

[12] F. Mancebo, L. Hilje, G. A. Mora and R. Salazar, "Biological Activity of Two Neem (Azadirachta indica A. Juss., Meliaceae) Products on Hypsipyla grandella (Lepidoptera: Pyralidae) Larvae," Crop Protection, Vol. 21, No. 2, 2002, pp. 107-112. doi:10.1016/S0261-2194(01)00069-2

[13] R. Chowdhury, "5-Methylcoumarins from Toona ciliata Stem Bark and Their Chemotaxonomic Significance," Biochemical Systematics and Ecology, Vol. 32, 2004, pp. 103-105. doi:10.1016/S0305-1978(03)00182-0

[14] A. T. Chatterjee, T. Chakraborthy and S. Chandrasekharan, "Chemical Investigation of Cedrela toona," Phytochemistry, Vol. 10, 1971, pp. 2533-2535. doi:10.1016/S0031-9422(00)89902-1

[15] L. M. Schoonhoven, "Secondary Plant Substances and Insects," Recent Advances in Phytochemistry, Vol. 4, 1972, pp. 197-242.

[16] L. H. Caporale, "Chemical Ecology: A View from the Pharmaceutical Industry," Proceedings of the National Academy of Sciences USA, Vol. 92, 1995, pp. 75-82. doi:10.1073/pnas.92.1.75

[17] S. Smolenski, H. Silinis and M. Farnworth, "Alkaloid Screening IV," Lloydia, Vol. 37, No. 1, 1974, pp. 30-61.

[18] P. Grijpma and S. C. Roberts, "Biological and Chemical Screening for the Basis of Resistance of Toona ciliata M.J. Roem. var. australis (F. \& M.) C.D.C.," Turrialba, Vol. 25, No. 2, 1975, pp. 152-159.

[19] J. G. Millar and J. J. Sims, "Preparation, Cleanup, and Preliminary Fractionation of Extracts," In: J. G. Millar and K. F. Haynes, Eds., Methods in Chemical Ecology, Chemical Methods, Vol. 1, Kluwer Academic Publishers, Boston, 1998, pp. 1-31.
[20] C. L. Céspedes, J. S. Calderón, L. Lina and E. Aranda, "Growth Inhibitory Effects on Fall Armyworm Spodoptera frugiperda of Some Limonoids Isolated from Cedrela spp. (Meliaceae)," Journal of Agricultural and Food Chemistry, Vol. 48, No. 5, 2000, pp. 1903-1908. doi:10.1021/jf990443q

[21] C. Vargas, P. J. Shannon, R. Taveras, F. Soto and L. Hilje, "Un Nuevo Método Para la Cría Masiva de Hypsipyla grandella," Hoja Técnica No. 39, Manejo Integrado de Plagas (Costa Rica), Vol. 62, 2001, pp. I-IV.

[22] D. Sliwa and V. O. Becker, "Studies on the Shootborer Hypsipyla grandella (Zeller) (Lep., Pyralidae). XXI. Observations on Emergence and Mating of Adults in Captivity," Turrialba, Vol. 23, 1973, pp. 351-356.

[23] SAS Institute, "SAS User's Guide: Statistical Analysis System," Version 8.2, SAS Institute Inc., Cary, 2001.

[24] R. Pavela, N. Vrchová and B. Šerá, "Growth Inhibitory Effect of Extracts from Reynoutria sp. Plants Against Spodoptera littoralis Larvae," Agrociencia, Vol. 42, No. 5, 2008, pp. 573-584.

[25] J. Pérez, S. Eigenbrode, L. Hilje, R. Tripepi, M. E. Aguilar and F. Mesén, "Leaves from Grafted Meliaceae Species Affect Survival and Performance of Hypsipyla grandella (Zeller) (Lepidoptera: Pyralidae) Larvae," Journal of Pest Sciences, Vol. 83, No. 2, 2010, pp. 95-104. doi:10.1007/s10340-009-0275-8

[26] W. T. Warthen, "Insect Feeding Deterrents (1976-1980)," In: E. Morgan and N. Mandava, Eds., CRC Handbook of Natural Pesticides, CRC Press, Boca Raton, 1990, pp. 23-24.

[27] R. Taveras, L. Hilje and M. Carballo, "Development of Hypsipyla grandella (Zeller) (Lepidoptera: Pyralidae) in Response to Constant Temperatures," Neotropical Entomology, Vol. 33, No. 1, 2004, pp. 1-6. doi:10.1590/S1519-566X2004000100002

[28] H. Rembole and K. P. Suber, "Inhibition of Oogenesis and Ovarian Ecdysteroid Synthesis by Azadirachtin in Locusta migratoria," Zeitschrift für Naturforschung, Vol. 36, 1981, pp. 466-469.

[29] X. D. Luo, S. H. Wu, Y. B. Ma and D. G. Wu, "Studies on Chemical Constituents of Toona sinensis," Chinese Traditional and Herbal Drugs, Vol. 32, No. 5, 2001, pp. 390-391.

[30] K. J. Wang, Ch. R. Yang and Y. Zhang, "Phenolic Antioxidants from Chinese Toon (Fresh Young Leaves and Shoots of Toona sinensis)," Food Chemistry, Vol. 101, No. 1, 2007, pp. 365-371.

doi:10.1016/j.foodchem.2006.01.044

[31] L. Hilje and J. Cornelius, "Es Inmanejable Hypsipyla grandella Como Plaga Forestal? Hoja Técnica No. 38," Manejo Integrado de Plagas (Costa Rica), Vol. 61, 2001, pp. I-IV.

[32] D. Cibrián, J. T. Méndez, R. Campos, H. O. Yates III and J. E. Flores, "Insectos Forestales de México," Universidad Autónoma Chapingo-Comisión Forestal de América del Norte (COFAN), Publ. No. 6, 1995, 453 p. 